\title{
Anti-HER-2 DNA vaccine protects Syrian hamsters against squamous cell carcinomas
}

\author{
GN Berta ${ }^{*, 1,3}$, B Mognetti ${ }^{1,3}$, M Spadaro', E Trione', A Amici², G Forni', F Di Carlo' and F Cavallo' \\ 'Department of Clinical and Biological Sciences, Ospedale San Luigi Gonzaga, University of Turin, I-10043 Orbassano, Italy; ${ }^{2}$ Department of Molecular, \\ Cellular and Animal Biology, University of Camerino, I-62032 Camerino, Italy
}

\begin{abstract}
This paper illustrates the efficacy of DNA vaccination through electroporation in the prevention of oral transplantable carcinoma in Syrian hamsters. At 21 and 7 days before tumour challenge, 19 hamsters were vaccinated with plasmids coding for the extracellular and transmembrane domains of rat HER-2 receptor (EC-TM plasmids), whereas 19 control hamsters were injected intramuscularly with the empty plasmid. Immediately following plasmid injection, hamsters of both groups received two square-wave 25 ms, $375 \mathrm{~V} \mathrm{~cm}^{-1}$ electric pulses via two electrodes placed on the skin of the injection area. At day 0 , all hamsters were challenged in the submucosa of the right cheek pouch with HER-2-positive HCPC I cells established in vitro from an 7, I2-dimethylbenz[a]anthraceneinduced oral carcinoma. This challenge gave rise to HER-2-positive buccal neoplastic lesions in I 4 controls (73.37\%), compared with only seven $(36.8 \%, P<0.0027)$ vaccinated hamsters. In addition, the vaccinated hamsters displayed both a stronger proliferative and cytotoxic response than the controls and a significant anti-HER-2 antibody response. Most of the hamsters that rejected the challenge displayed the highest antibody titres. These findings suggest that DNA vaccination may have a future in the prevention of HER-2positive human oral cancer.
\end{abstract}

British Journal of Cancer (2005) 93, 1250 - 1256. doi:I0.1038/sj.bjc.6602853 www.bjcancer.com

Published online I November 2005

(c) 2005 Cancer Research UK

Keywords: oral squamous cell carcinoma; cancer vaccine; DNA vaccination; HER-2; immunoprevention

Neoplasms of the oral cavity constitute about $3 \%$ of all malignancies worldwide (Parkin et al, 2001) and their continuous increase to the point of becoming a public health problem in the foreseeable has been predicted by the World Health Organization (http://www.who.int/topics/oral_health/en). Oral squamous cell carcinoma (OSCC) accounts for about $90 \%$ of cases. It may be preceded by various lesions and is a complex disease because of its location and patterns of spread. Treatment is essentially determined by site and stage as well as the patient's general health (Vokes et al, 1993). Survival rates, however, have not improved over the last 20 years and $50-70 \%$ of patients die within 5 years due to local recurrences, metastasis and a second primary cancer (Day and Blot, 1992). Surgery is still the treatment of choice, but often results in chronic pain, speech and swallowing impediments, and irreparable, disfiguring impairments (Mort Telfer and Shepherd, 1993; de Cassia Braga Ribeiro et al, 2003).

The alarming epidemiological data, the poor prognosis and the unsatisfactory quality of life of patients with OSCC call for the urgent elaboration of a new way to treat it. Recent preclinical and clinical studies of immunopharmacological methods have shown that they can be effective against melanoma (Nestle et al, 1998; Rosenberg et al, 1998), lymphoma (Hsu et al, 1996), kidney (Kugler et al, 2000), prostate (Murphy et al, 1999), colorectal (Morse et al, 1999) and head and neck cancers (Cortesina et al,

*Correspondence: Dr GN Berta; E-mail: giovanni.berta@unito.it

${ }^{3}$ These authors contributed equally to this work

Revised 24 August 2005; accepted 3 October 2005; published online I November 2005
1994; Wollenberg et al, 1999; De Stefani et al, 2002). Anticancer vaccines constitute a specific approach whose efficacy depends on how well the target tumour antigens are defined and whether there are conserved antigens shared by tumours of the same histotype in many individuals (Gilboa, 2004). The literature shows that HER-2 is one of the most common oncogenes overexpressed in OSCC (Chen et al, 2003). It encodes for a tyrosine-kinase receptor (p185) belonging to the family of epidermal growth factor receptors. Increased expression or mutation of p185 induces a proliferation signal in a ligand-independent way. p185 is therefore believed to be involved in the triggering and progression of many epithelial tumours (Ignatoski et al, 1999). Impressive results have been achieved by targeting p185, particularly in transgenic mice that inevitably develop spontaneous tumours. DNA vaccination with plasmids coding for the transmembrane and extracellular domains of the rat p185 (EC-TM plasmids) elicits a protective immune response against spontaneously arising mammary tumours in $\mathrm{BALB} / \mathrm{c}$ mice transgenic for the gene encoding the mutated form of the rat p185 (Rovero et al, 2000; Di Carlo et al, 2001; Dela Cruz et al, 2003; Quaglino et al, 2004a). This form of vaccination has many ideal features: induction of both humoral and cellular immune responses, long-lasting immunity and simple and cheap production. The first generation of experiments have shown that delivery of DNA constructs encoding a specific immunogen safely elicits well-tolerated responses in a variety of animal models (Lowrie, 2003). Even better results are obtained when the entry of DNA into target cells is facilitated by electroporation, a technique in which short high-voltage pulses are used to form pores in the cell membrane (Gehl, 2003). This paper illustrates the efficacy of DNA vaccination through EC-TM plasmid electroporation (EC-TM 
DNA-vax) in the prevention of oral cancer in an orthotopic Syrian hamster model of transplantable tumour. The OSCC line (HCPC I) injected into hamster cheek pouches was established from an epidermoid carcinoma induced through in vivo applications of 7,12-dimethylbenz[a]anthracene (Salley, 1954; Odukoya et al, 1983). Our findings indicate that EC-TM DNA-vax may have a future in the treatment of HER-2-positive human oral cancer, especially in the prevention of its development after surgical removal of an initial OSCC or as the sequel of a precancerous lesion.

\section{MATERIALS AND METHODS}

\section{Cell lines}

The HCPC I line established from a chemically induced epidermoid carcinoma of the Syrian hamster (Odukoya et al, 1983) was kindly provided by Professor DT Wong (UCLA, Los Angels, CA, USA). N202.1A and N202.1E, which are positive and negative for rat HER-2 expression, respectively, are clonal derivatives of the established N202.1 cell line derived from a mammary carcinoma of FVB-neuN\#202 mice, transgenic for the rat neu proto-oncogene (Nanni et al, 2000). SKBr3 (American Type Culture Collection, Manassas, VA, USA) is a human breast cancer cell line that overexpresses the HER-2 gene product. Wild-type $\mathrm{BALB} / \mathrm{c} 3 \mathrm{~T} 3$ fibroblasts and BALB/C $3 \mathrm{~T} 3$ fibroblasts stably cotransfected with the wild-type rat HER-2/neu and mouse class I $\mathrm{H}-2 \mathrm{~K}^{\mathrm{d}}$ and $\mathrm{B} 7.1$ genes (BALB/c 3T3-NKB cells) (Spadaro et al, 2005) were kindly provided by Dr Wei-Zen Wei (Karmanos Cancer Institute, Detroit, MI, USA). Cells were cultured in DMEM (SigmaAldrich, St Louis, MO, USA) with $75 \mathrm{U} \mathrm{ml}^{-1}$ penicillin G, $100 \mu \mathrm{g} \mathrm{ml}^{-1}$ kanamycin sulphate and $1 \mu \mathrm{g} \mathrm{ml}^{-1}$ amphotericin $\mathrm{B}$ (all from Sigma) at $37^{\circ} \mathrm{C}$ in a humidified $5 \% \mathrm{CO}_{2}$ atmosphere. For HCPC I and SKBr3, the medium was supplemented with $10 \%$ fetal calf serum (FCS) (Cambrex, Walkersville, MD, USA), whereas for $\mathrm{N} 202.1 \mathrm{~A}, \mathrm{~N} 202.1 \mathrm{E}, \mathrm{BALB} / \mathrm{c} 3 \mathrm{~T} 3$ and BALB/c 3T3-NKB cultures it was supplemented with $20 \%$ FCS. Neomycin $\left(600 \mu \mathrm{g} \mathrm{ml}^{-1}\right)$ and Zeocin $\left(600 \mu \mathrm{g} \mathrm{ml}^{-1}\right)$ (Invitrogen Corp., Carlsbad, CA, USA) were added to the BALB/c 3T3-NKB cell medium.

\section{Immunoprecipitation and Western blot analysis}

HCPC I, N202.1A and N202.1E cell monolayers were collected and prepared by homogenisation in protein loading buffer. Total proteins $(20 \mu \mathrm{g})$ were separated on an $8 \%$ SDS - polyacrylamide gel, and electrotransferred to a Hybond-C nitrocellulose membrane (Amersham Pharmacia Biotech, Little Chalfont, UK). Western blot analysis was performed with the mouse monoclonal antibody (mAb) Ab-3 (Oncogene Research Products, Cambridge, MA, USA). The membrane was then exposed to the appropriate horseradish peroxidase-conjugate secondary antibody $(1: 5000)$ (Sigma) for $1 \mathrm{~h}$ at room temperature and labelled bands were detected with a chemiluminescence commercial kit (Immun-Star ${ }^{\mathrm{TM}}$, Bio-RadHercules, CA, USA). Image acquisition of the immunoreactive bands was performed with a Kodak Image Station 440CF (Kodak, Rochester, NY, USA).

Immunoprecipitation of tumour, healthy tissue and HCPC I was performed by incubating samples with the rabbit polyclonal antibody Sc-284 (Santa Cruz Biotechnology, Santa Cruz, CA, USA) and with Protein A-sepharoses (Sigma), equilibrated in lysis buffer and conjugated with anti-rabbit IgG (Sigma). After immunoprecipitation, immune complexes were washed, eluted, heated for $5 \mathrm{~min}$ at $95^{\circ} \mathrm{C}$ in reducing sample buffer and processed as described for total samples. Immunoprecipitated proteins were revealed with a pool of DNA-vax or control hamster sera diluted $1: 10$, and the secondary antibody peroxidase-conjugated Affini-
Pure Rabbit anti-Syrian hamster IgG (Jackson ImmunoResearch, West Grove, PA, USA).

\section{Flow cytometry}

HCPC I cells were stained with Ab-3, which recognises an intracellular domain of $\mathrm{p} 185$; $\mathrm{SKBr} 3$ cells were used as a control of high Her-2 expression. The anti-mouse FITC-conjugated secondary antibody (1:5000) (Dako, Glostrup, Denmark) was used to detect bound primary antibodies. Before staining, the cells were permeabilised with phosphate-buffered saline (PBS) supplemented with $1 \%$ FCS and $0.5 \%$ Tween 20 . Analysis was performed with a FACscan (Beckton Dickinson, Mountain View, CA, USA) and the cells were gated by size and granularity. The data were analysed through CellQuest (Beckton Dickinson).

\section{Hamsters and HCPC I cell challenge}

Thirty-eight 4-6-week-old male Syrian hamsters (Charles River Laboratories Italy, Calco, Italy) were maintained in specific pathogen-free conditions with a $12 \mathrm{~h}$ light-dark cycle and rodent chow and tap water ad libitum. They were challenged (day 0 ) with $1.8 \times 10^{7}$ HCPC I cells in $0.2 \mathrm{ml}$ of PBS injected with a 20-gauge needle syringe in the submucosa of the everted and stretched out right cheek pouch. They were then checked weekly to monitor lesion progression and, 5 weeks from the beginning of the experiments, anesthetised, bled and killed. The spleen was collected for the cytotoxicity assay, while all the main organs were inspected macroscopically. All procedures were carried out in accordance with the Guidelines for the Welfare of Animals in Experimental Neoplasia (UKCCCR, 1998).

\section{Injection and electroporation of EC-TM plasmids}

pcDNA3 vector coding the extracellular and transmembrane domains of rat HER-2 receptor was produced and used as described (Rovero et al, 2000). Briefly, DNA was precipitated, suspended in sterile saline at $1.25 \mathrm{mg} \mathrm{ml}^{-1}$, and stored in aliquots at $-20^{\circ} \mathrm{C}$ for use in immunisation protocols. For DNA electroporation, $50 \mu \mathrm{g}$ of EC-TM or empty plasmids in $40 \mu \mathrm{l}$ of $0.9 \% \mathrm{NaCl}$ with $6 \mathrm{mg} \mathrm{ml}^{-1}$ polyglutamate were injected into the tibial muscle of both legs of anesthetised hamsters 21 and 7 days before tumour challenge (day 0). Electric pulses were applied by two electrodes placed on the shaved skin of the injection area covered with a conducting gel. Two square-wave $25 \mathrm{~ms}, 375 \mathrm{~V} \mathrm{~cm}^{-1}$ pulses were generated by a T820 electroporator (BTX, San Diego, CA, USA).

\section{Histology and immunohistochemistry}

Tissue samples and cells were fixed and embedded in paraffin. Sections $(4 \mu \mathrm{m})$ were cut and stained with haematoxylin and eosin or analysed for expression of HER-2 using the Sc-284 Ab, or of pancytokeratins with the C-1801 mouse $\mathrm{mAb}$ (Sigma). The binding of Sc-284 on fixed samples was evaluated with a Dako En Vision ${ }^{\mathrm{TM}}$ Plus System (Dako Corporation, Carpinteria, CA, USA). Peroxidase activity was displayed by $3-3^{\prime}$-diaminobenzidinetetrahydrochloride (Dako Corporation) and a haematoxylin solution was used for nuclear staining. Paraffin sections from mammary carcinomas with known HER-2 expression were used as positive controls. Staining was graded from 0 (negative) to 3 (strong complete membrane staining) according to the manufacturer's instructions (Dako Hercept Test, 2000). On fresh cells growing on a Lab-Tek chamber slide (Nalge Nunc Int, Naperville, IL, USA), after nuclear staining with propidium iodide, Sc-284 and C-1801 binding was demonstrated with the appropriate FITC-conjugated Ab. Images were captured with an Axiovert Zeiss microscope (Zeiss, Axiovert $100 \mathrm{M}$ ). 


\section{Cellular reactivity}

In the proliferative assay, $4 \times 10^{5}$ spleen cells $(\mathrm{Spc})$ from control and EC-TM DNA-vax hamsters were cultured with $2 \times 10^{4}$ HCPC I cells in $200 \mu \mathrm{l}$ of medium supplemented with $10 \mathrm{U} \mathrm{ml}^{-1}$ of recombinant IL-2 (Eurocetus, Milan, Italy) in quadruplicate in microtitre wells at $37^{\circ} \mathrm{C}$ in a humidified $5 \% \mathrm{CO}_{2}$ atmosphere. After $24 \mathrm{~h}$, cells were pulsed for $48 \mathrm{~h}$ with BrdU labelling solution. BrdU uptake was detected with the Cell Proliferation ELISA BrdU Kit (Roche Diagnostic GmbH, Mannheim, Germany) and expressed as optical density (OD). To assess cytotoxicity, $1 \times 10^{7} \mathrm{Spc}$ were stimulated for 6 days with $5 \times 10^{5}$ mitomycin-C (Sigma)-treated HCPC I cells in the presence of $10 \mathrm{U} \mathrm{ml}^{-1} \mathrm{IL}-2$ and assayed in a $48 \mathrm{~h}\left[{ }^{3} \mathrm{H}\right] \mathrm{TdR}$ release assay at effector-to-target ratios from $50: 1$ to $6: 1$ in round-bottom, 96-well microtitre plates in triplicate, as previously described in detail (Cappello et al, 2003). The results were expressed both as percentage of cytotoxicity and as lytic units $(\mathrm{LU})_{20}$ per $10^{7}$ effector cells, with $\mathrm{LU}_{20}$ defined as the number of effector cells needed to kill $20 \%$ of the target cells (Cavallo et al, 1992).

\section{Antibody response}

Sera obtained at progressive time points from control and EC-TM DNA-vax hamsters were diluted 1:100 in PBS-azide-bovine serum albumin (Sigma), and the presence of anti-p185 Ab was determined by flow cytometry using BALB/c 3T3-NKB cells. FITC-conjugated goat anti-hamster Ab specific for hamster IgG (heavy and light chains) (ImmunoKontact, Abingdon, Oxon, UK) was used to detect bound primary Ab. Normal hamster serum was the negative control. mAb Ab-4 (Oncogene) was used as a positive control. Serial Ab-4 dilutions were used to generate a standard curve to determine the concentration $\left(\mu \mathrm{g} \mathrm{ml}^{-1}\right)$ of anti-p185 Ab in serum (Spadaro et al, 2005).

\section{Statistics}

Differences in tumour numbers were evaluated using Fisher's exact test. Data on cytotoxicity, lymphocyte proliferation and antibody level were evaluated with a two-tailed Student's $t$-test.

\section{RESULTS}

\section{HER-2 expression by HCPC I cells}

As shown by Western blot analysis with mouse N202.1A and $\mathrm{N} 202.1 \mathrm{E}$ cells as HER-2-positive and -negative controls, HCPC I cells express p185 receptor (Figure $1 \mathrm{~A}$ ).

Immunostaining of adhering cells (Figure 1B) showed a predominant cell membrane p185 expression; immunohistochemistry of paraffin-embedded HCPC I (Figure 1C, D) showed a medium-high p185 expression $(2+)$ in almost all cells (as compared with breast carcinoma specimens, not shown, according to the manufacturer's instructions) (Dako Hercept Test, 2000). After staining the cells with Ab-3 recognising p185, flow cytometry showed that HCPC I cells were HER-2 positive (Figure 1E). SKBr3, which are known to highly overexpress HER-2, were used as a positive control (Figure 1F).

\section{Growth of HCPC I tumour cells in Syrian hamsters}

At 5 weeks after HCPC I cell challenge, 14 out of 19 hamsters $(73.37 \%)$ injected with the empty plasmid 21 and 7 days before challenge displayed buccal lesions (mean 3-11 mm). Six hamsters presented small nodules, three of which were associated with mucosal ulceration, while eight showed irregularly shaped white plaques. Irrespective of the gross appearance, all lesions had the microscopical features of invasive squamous carcinoma. The lesions were characterised by solid nests and cords composed of large roundish or, more commonly, elongated neoplastic cells, with occasional atypias, an hyperchromatic nucleus and numerous mitoses, extensively infiltrating the wall of the pouch mucosa and underlying striated muscle fibres. In some cases, the overlying mucosa was invaded and ulcerated. Keratin pearls and multinucleated cells were occasionally observed. Foci of necrosis were present in most cases (Figure 2A and B). The epithelial origin of the infiltrating cells was confirmed by immunohistochemical expression of cytokeratin (Figure 2C, D and E). The tumour cells were also focally positive for HER-2, with preferential peripheral or membrane staining (Figure $2 \mathrm{~F}$ ). In the five tumour-free hamsters, the whole tissue challenge areas displayed only an inflammatory and fibrotic reaction. A dense fibrous tissue nodule containing
A

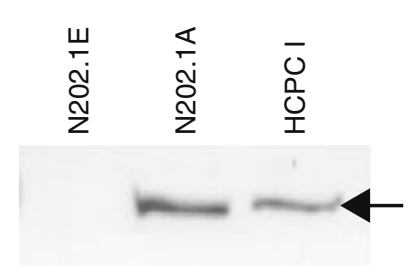

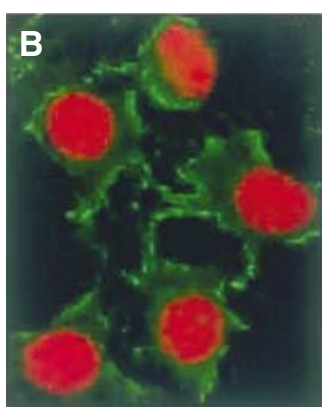
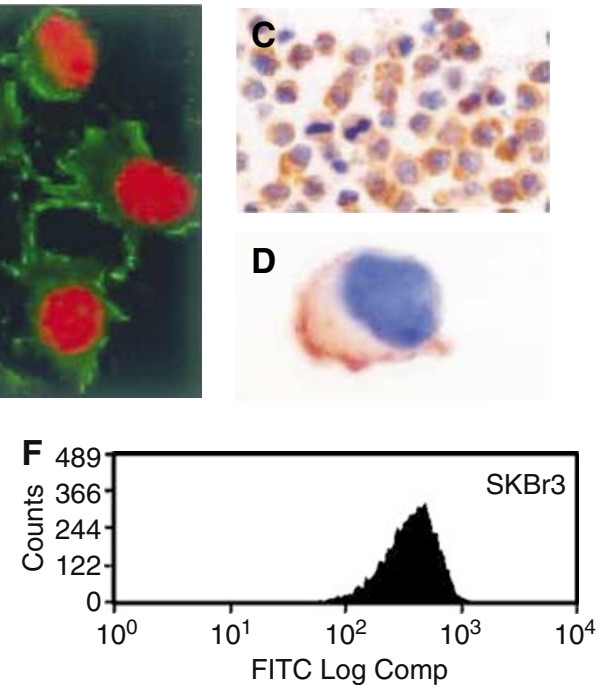

Figure I pl85 expression by HCPC I. (A) Western blot analysis revealed by Ab-3: N202.IE is the negative control, N202. IA the positive control; the arrow indicates a molecular weight of $185 \mathrm{kDa}$; (B) Sc-284 p 185 localisation in adherent HCPC I shown by green fluorescent immunostaining. Nuclei are stained red. (Original magnification: $\times 600$ ). (C, D) Immunocytochemical expression of pl 85 by HCPC I revealed by Sc-284. A predominant membrane staining is shown (original magnification: $\mathbf{C} \times 200$; $\mathbf{D} \times 1000$ ). (E, F) FACs analysis performed with mAb Ab-3. In $(\mathbf{E}) \mathrm{HCPC}$ I staining is shown, and in $(\mathbf{E})$ $\mathrm{SKBr} 3$ are used as a positive control. 

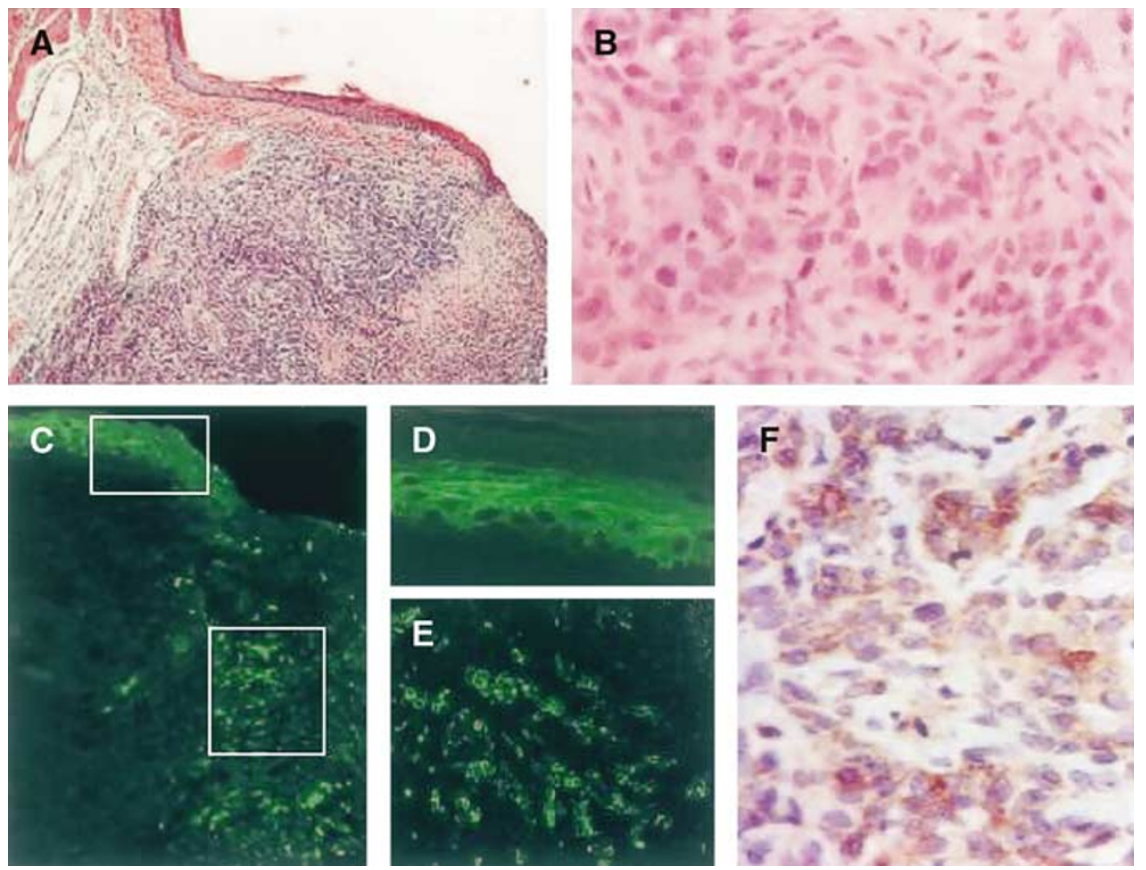

Figure 2 Histology and immunohistochemistry of neoplastic lesions induced in hamster cheek pouches by HCPC I. (A) Undifferentiated SCC ( $\times 25)$. At higher magnification $(\mathbf{B}, \times 400)$, cellular pleomorphism, numerous mitoses and large hyperchromatic nuclei are present in elongated neoplastic cells. Haematoxylin and eosin staining. Indirect immunofluorescent staining for pancytokeratin confirms the epithelial origin of the tumour infiltrating cells (C) $\times 25, \mathbf{E}, \times 200)$. The positive control is the normal epithelium $(\mathbf{D}, \times 200)$. pl 85 expression is maintained in inoculated HCPC I cells with a predominant peripheral or membrane cell distribution $(\mathbf{F}$, immunoperoxidase, $\times 400)$.

occasional inflammatory cells, but no tumour cells (as confirmed by negative cytokeratin staining) was seen in two hamsters (data not shown).

\section{Anti-HER-2 DNA vaccine protects against HCPC I cell challenge}

Only seven out of $19(36.8 \%, P<0.0027)$ hamsters vaccinated with EC-TM plasmids 21 and 7 days before challenge displayed a neoplastic lesion. Five displayed a nodular mass, the other two a white plaque only. The histological features of these lesions were similar to those of the controls. No signs of acute toxicity or weight differences were associated with EC-TM DNA-vax.

\section{Cell reactivity}

To see whether enhanced cell reactivity was associated with the protection afforded by EC-TM DNA-vax, the proliferative and cytotoxic response of Spc from EC-TM-vaccinated and control hamsters to HCPC I cells was assessed at the end of the experiment. Following in vitro restimulation, Spc from EC-TMvaccinated hamsters displayed a stronger proliferative (Figure $3 \mathrm{~A}$ ) and cytotoxic response (Figure $3 \mathrm{~B}$ ) than those from control hamsters.

\section{Anti-HER-2 antibodies}

A significant anti-HER-2 antibody response was detected in sera collected the day before HCPC I challenge from the immunised hamsters. Most of the hamsters that rejected the challenge displayed the highest antibody titres (Figure 4A). These titres were much the same 5 weeks later.

The specificity of those antibodies was confirmed by Western blot. After immunoprecipitation, sera from DNA-vax hamsters recognised the p185 expressed by HCPC I and by tumour tissue but not from healthy controlateral pouch mucosa (Figure 4B). No staining was obtained by sera of control hamsters (data not shown).

\section{DISCUSSION}

This is probably the first demonstration that a protective immune response against HER-2 can be elicited in hamsters by EC-TM DNA-vax as in mice transgenic for the rat HER-2 that develop mammary carcinomas (Rovero et al, 2000; Quaglino et al, 2004a). Electroporation of plasmids coding for the EC and TM portion of rat HER-2 elicits both T-cell reactivity and antibody response. The direct correlation between the anti-HER-2 Ab titre and rejection of HCPC I suggests that antibodies make a substantial contribution to this protection as in HER-2 transgenic mice (Rovero et al, 2000; Nanni et al, 2004; Park et al, 2005).

Plasmids coding rat HER-2 were employed because xenogeneic immunisation is an effective way to break tolerance and induce $\mathrm{T}$ cells and antibodies crossreacting with the self, tolerated protein (Bowne et al, 1999; Overwijk et al, 1999). Hamster and rat HER-2 proteins share $94.2 \%$ sequence similarity (Swiss Prot; www.expasy.org) and long homologous sequences are intercalated with heterologous amino-acid sequences. T-helper cell reactivity against non tolerated rat peptides assists activation of the $\mathrm{B}$ cells that will produce antibodies against both rat and hamster HER-2 (Trojan et al, 2001). Moreover, in the nine fragments recognised as the most immunogeneic of the EC and TM domains according to Ogiso et al (2002), six out of 10 substitutions are conservative. In addition, xenogeneic sequences may give rise to 'heteroclitic' peptides that may have a higher affinity for hamster MHC glycoproteins than homologous peptides (Dyall et al, 1998).

Vaccination with DNA coding for rat HER-2, in fact, elicits a significant cell $(P=0.009)$ and antibody $(P=0.0024)$ reaction 
A
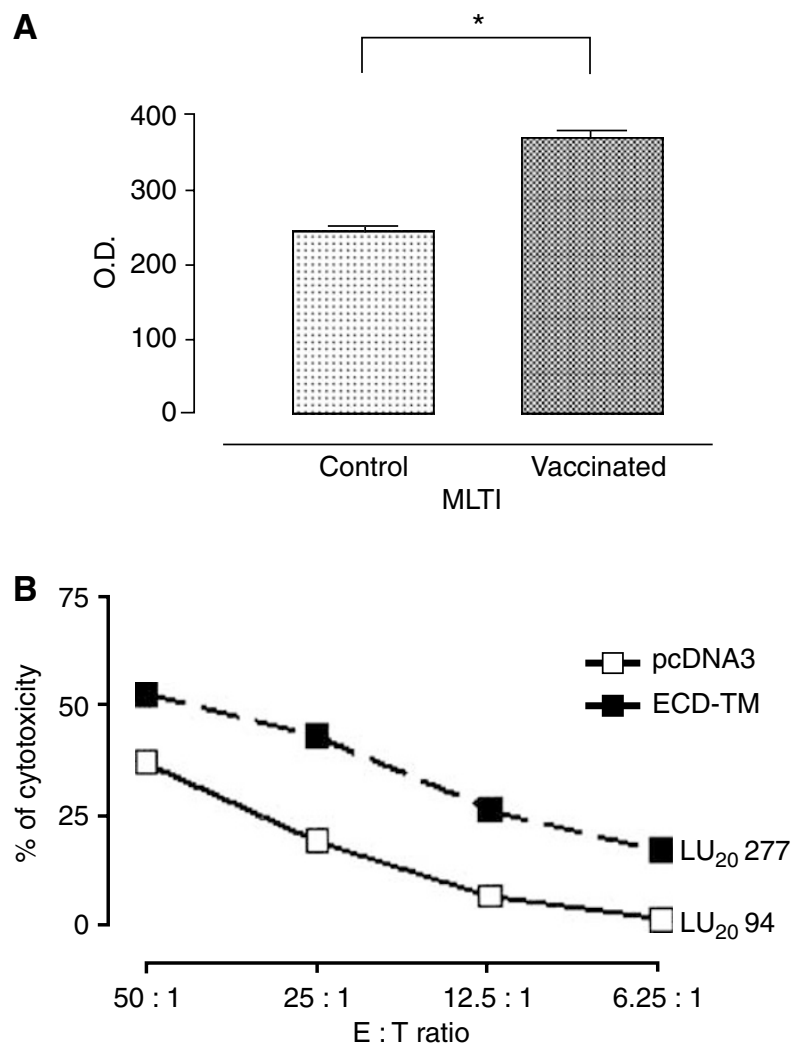

Figure 3 Cellular reactivity. (A) Proliferative response. Spc were restimulated for $48 \mathrm{~h}$ with $\mathrm{HCPC}$ I cells in the presence of BrdU. Results are from one of three independent experiments in which each sample was prepared in triplicate $(* P<0.05)$. (B) Cytotoxicity. Spc cytotoxicity evaluated in a $48 \mathrm{~h}{ }^{3} \mathrm{H}$ thymidine release assay against HCPC I (filled squares, hamsters vaccinated with EC-TM plasmids; empty squares hamsters vaccinated with empty plasmid $)(P=0.009)$. Data from an experiment representative of three similar experiments are shown.

against hamster HER-2. The absence of obvious autoimmune lesions may be due to poor expression of HER-2 by adult hamster tissues.

The appearance of a significant anti-HER-2 antibody response following electroporation points to T-helper and B-cell activation. Previous work with transgenic mice has illustrated the fundamental role of antibodies in checking the progression of HER-2 carcinoma (Rovero et al, 2000; Nanni et al, 2004; Quaglino et al, 2004a; Park et al, 2005). An arbitrary threshold of $11.5 \mu \mathrm{g} \mathrm{ml}^{-1}$ can be used to divide the vaccinated hamsters into those with high and those with low anti-HER-2 antibody titres. Tumour takes were higher in the low-titre hamsters (Figure 4A). The antitumour effects of antibodies directed against membrane tyrosine kinase receptors such as p185 include the blockade of mitogenic signal transduction through inhibition of receptor dimerisation and induction of internalisation and recycling, along with immunemediated functions, namely complement-mediated cytotoxicity and antibody-dependent cellular cytotoxicity (Rovero et al, 2000, Nanni et al, 2004; Quaglino et al, 2004b). Although transplantable tumours may not reflect a few features of the human cancer, we studied HCPC I cells because the biological and histological characteristics of the tumours they form in hamsters are actually very similar to human SCC. In addition, they are from one of the best-characterised animal models for oral cancer, overexpresses p185 receptors and are transplantable to immunocompetent random-bred hamsters. This is probably the first demonstration of the efficacy of specific immunisation in the control of OSCC. Its
A
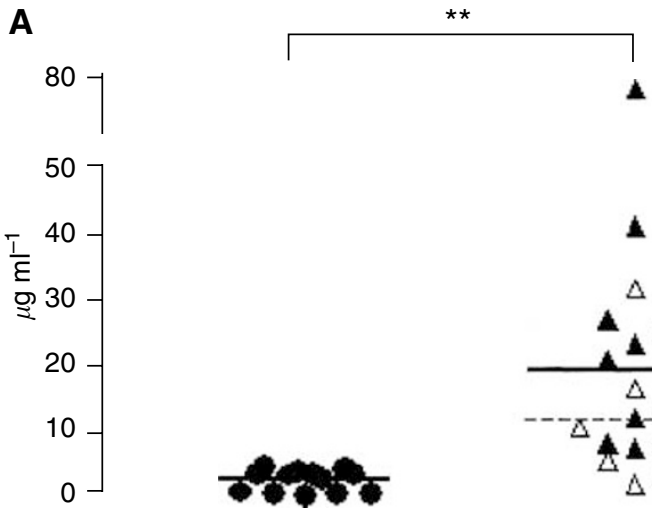

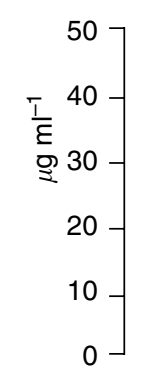
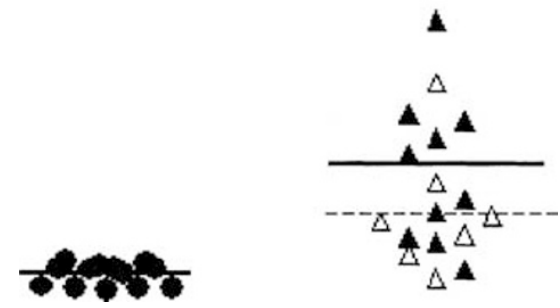

Control

Vaccinated

B

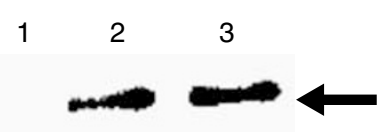

Figure 4 Specific antibodies against p|85. (A) Anti p /85-antibody titre in vaccinated and control animals. Mean antibody titres are indicated by full line $(* * P=0.0024)$. Antibody titre of EC-TM DNA-vax hamsters is correlated to vaccination outcome: black and empty triangles represent tumour-rejecting and tumor-bearing animals, respectively. Only two out of seven tumour-bearing hamsters displayed an antibody titre above $11.5 \mu \mathrm{g} \mathrm{m} l^{-1}$ (dotted line). (B) Extracts of healthy mucosa (lane I), tumour tissue (lane 2) and HCPC I (lane 3) immunoprecipitated by Sc-284 and revealed with pooled sera from DNA-vax hamsters. The arrow indicates a molecular weight of I $85 \mathrm{kDa}$.

significance is enhanced by the fact that a high percentage of OSCC overexpresses p185 receptors (Xia et al, 1999; Chen et al, 2003) and its extension, via a similar protocol, to another kind of cancer, of the evidence of the ability of DNA electroporation to evoke an efficient immune response to prevent mammary carcinoma in HER-2 transgenic mice (Quaglino et al, 2004a). Hamsters are naturally tolerant to the self-endogenous p185 protein and DNA electroporation overcame such tolerance. The hamster cheek pouch is an ideal site for the implantation of tissues and cells, both from other species and humans (Lutz and Patt, 1952; Handler et al, 1956; Resnick et al, 1960), since it is not an immunologically privileged site and immunosuppressive and immunostimulating agents can modulate the intensity of the local immune response (Shklar et al, 1979). Transplantability of HCPC I cells to randombred hamsters rests on the monomorphic aspect of their major histocompatibility complex (Billingham and Hildemann, 1958; Palm et al, 1967). This peculiarity serves to illustrate the efficacy of DNA vaccination against HER-2 in a genetically heterogeneous (not inbred) population displaying some features similar to those in human. This heterogeneity may account for the much higher dispersion of the anti-HER-2 Ab titres after DNA electroporation by comparison with inbred mice (Rovero et al, 2000; Quaglino et al, 2004a, b).

As no major toxic effects were associated with DNA electroporation, or with the stimulation of a significant anti-HER-2 immune response, the use of DNA electroporation could be considered in OSCC prevention, especially the predominantly local and regional recurrences noted in OSCC patient. Furthermore, it is a relatively low-cost technology that could also be afforded by developing countries, such as India, Bangladesh and Sri Lanka with their high incidence of OSCC and prevalence of HER-2positive OSCC due to the consumption of betel quid (Chen et al, 2003). 


\section{ACKNOWLEDGEMENTS}

We thank Professor Mauro Papotti, Dott Susanna Cappia and Dott Giovanna Corvetti for their assistance in pathological reports and Professor John Iliffe for editing the manuscript. This work was supported by the Italian Association for Cancer Research, the project Ricerca Sanitaria Finalizzata Regione Piemonte, the Italian Ministries for the University and Health, the University of Torino, and the Compagnia di San Paolo. BM and ET are supported by a grant from Ricerca Scientifica Applicata, Regione Piemonte.

\section{REFERENCES}

Billingham RE, Hildemann WH (1958) Studies of transplantation immunity in hamsters. Ann N Y Acad Sci 73: 676-686

Bowne WB, Srinivasan R, Wolchok JD, Hawkins WG, Blachere NE, Dyall R, Lewis JJ, Houghton AN (1999) Coupling and uncoupling of tumor immunity and autoimmunity. J Exp Med 190: 1717-1722

Cappello P, Triebel F, Iezzi M, Caorsi C, Quaglino E, Lollini PL, Amici A, Di Carlo E, Musiani P, Giovarelli M, Forni G (2003) LAG-3 enables DNA vaccination to persistently prevent mammary carcinogenesis in HER-2/ neu transgenic BALB/c mice. Cancer Res 63: 2518-2525

Cavallo F, Giovarelli M, Gulino A, Vacca A, Stoppacciaro A, Modesti A, Forni G (1992) Role of neutrophils and CD4+ T lymphocytes in the primary and memory response to nonimmunogenic murine mammary adenocarcinoma made immunogenic by IL-12 gene transfection. J Immunol 149: 3627-3635

Chen IH, Chang JT, Liao CT, Wang HM, Hsieh LL, Cheng AJ (2003) Significance of EGFR and Her-2 in oral cavity cancer in betel quid prevalent area cancer prognosis. Br J Cancer 89: 681-686

Cortesina G, De Stefani A, Galeazzi E, Cavallo GP, Badellino F, Margarino G, Jemma C, Forni G (1994) Temporary regression of recurrent squamous cell carcinoma of the head and neck is achieved with a low but not with a high dose of recombinant interleukin 2 injected perilymphatically. Br J Cancer 69: $572-576$

Dako HercepTest ${ }^{\mathrm{TM}}$ (2000) A Manual for Interpretation, pp 7-8

Day GL, Blot WJ (1992) Second primary tumors in patients with oral cancer. Cancer 70: $14-19$

de Cassia Braga Ribeiro K, Kowalski LP, Latorre Mdo R (2003) Perioperative complications, comorbidities, and survival in oral or oropharyngeal cancer. Arch Otolaryngol Head Neck Surg 129: 219-228

Dela Cruz JS, Lau SY, Ramirez EM, De Giovanni C, Forni G, Morrison SL, Penichet ML (2003) Protein vaccination with the HER2/neu extracellular domain plus anti-HER2/neu antibody-cytokine fusion proteins induces a protective anti-HER2/neu immune response in mice. Vaccine 21: $1317-1326$

De Stefani A, Forni G, Ragona R, Cavallo G, Bussi M, Usai A, Badellino F, Cortesina G (2002) Improved survival with perilymphatic interleukin 2 in patients with resectable squamous cell carcinoma of the oral cavity and oropharynx. Cancer 95: 90-97

Di Carlo E, Rovero S, Boggio K, Quaglino E, Amici A, Smorlesi A, Forni G, Musiani P (2001) Inhibition of mammary carcinogenesis by systemic interleukin 12 or p185neu DNA vaccination in Her-2/neu transgenic BALB/c mice. Clin Cancer Res 7: $830-837 \mathrm{~s}$

Dyall R, Bowne WB, Weber LW, LeMaoult J, Szabo P, Moroi Y, Piskun G, Lewis JJ, Houghton AN, Nikolic-Zugic J (1998) Heteroclitic immunization induces tumor immunity. J Exp Med 188: $1553-1561$

Gehl J (2003) Electroporation: theory and methods, perspectives for drug delivery, gene therapy and research. Acta Physiol Scand 177: 437-447

Gilboa E (2004) The promise of cancer vaccines. Nat Rev Cancer 4: 401 - 411

Handler AH, Davis S, Sommers SC (1956) Heterotransplantation experiments with human cancers. Cancer Res 16: $32-36$

Hsu FJ, Benike C, Fagnoni F, Liles TM, Czerwinski D, Taidi B, Engleman EG, Levy R (1996) Vaccination of patients with B-cell lymphoma using autologous antigen-pulsed dendritic cells. Nat Med 2: 52-58

Ignatoski KM, Lapointe AJ, Radany EH, Ethier SP (1999) erbB-2 overexpression in human mammary epithelial cells confers growth factor independence. Endocrinology 140: 3615-3622

Kugler A, Stuhler G, Walden P, Zoller G, Zobywalski A, Brossart P, Trefzer U, Ullrich S, Muller CA, Becker V, Gross AJ, Hemmerlein B, Kanz L, Muller GA, Ringert RH (2000) Regression of human metastatic renal cell carcinoma after vaccination with tumor cell-dendritic cell hybrids. Nat Med 6: $332-336$

Lowrie DB (2003) DNA vaccination: an update. Methods Mol Med 87: $377-390$

Lutz BR, Patt DI (1952) I. White thromboembolism in the hamster cheek pouch after trauma, infection, and neoplasia; II. The use of the hamster cheek pouch as a site for homologous and heterologous tumor transplantation. Bull N Engl Med Cent 14: 58-60

Morse MA, Deng Y, Coleman D, Hull S, Kitrell-Fisher E, Nair S, Schlom J, Ryback ME, Lyerly HK (1999) A phase I study of active immunotherapy with carcinoembryonic antigen peptide (CAP-1)-pulsed, autologous human cultured dendritic cells in patients with metastatic malignancies expressing carcinoembryonic antigen. Clin Cancer Res 5: 1331-1338

Mort Telfer MR, Shepherd JP (1993) Psychological distress in patients attending an oncology clinic after definitive treatment for maxillofacial malignant neoplasia. Int J Oral Maxillofac Surg 22: 347-349

Murphy GP, Tjoa BA, Simmons SJ, Jarisch J, Bowes VA, Ragde H, Rogers M, Elgamal A, Kenny GM, Cobb OE, Ireton RC, Troychak MJ, Salgaller ML, Boynton AL (1999) Infusion of dendritic cells pulsed with HLA-A2specific prostate-specific membrane antigen peptides: a phase II prostate cancer vaccine trial involving patients with hormone-refractory metastatic disease. Prostate 38: 73-78

Nanni P, Landuzzi L, Nicoletti G, De Giovanni C, Rossi I, Croci S, Astolfi A, Iezzi M, Di Carlo E, Musiani P, Forni G, Lollini PL (2004) Immunoprevention of mammary carcinoma in HER-2/neu transgenic mice is IFN-gamma and B cell dependent. J Immunol 173: 2288-2296

Nanni P, Pupa SM, Nicoletti G, De Giovanni C, Landuzzi L, Rossi I, Astolfi A, Ricci C, De Vecchi R, Invernizzi AM, Di Carlo E, Musiani P, Forni G, Menard S, Lollini PL (2000) p185(neu) protein is required for tumor and anchorage-independent growth, not for cell proliferation of transgenic mammary carcinoma. Int J Cancer 87: $186-194$

Nestle FO, Alijagic S, Gilliet M, Sun Y, Grabbe S, Dummer R, Burg G, Schadendorf D (1998) Vaccination of melanoma patients with peptideor tumor lysate-pulsed dendritic cells. Nat Med 4: 328-332

Odukoya O, Schwartz J, Weichselbaum R, Shklar G (1983) An epidermoid carcinoma cell line derived from hamster 7,12-dimethylbenz[a]anthracene-induced buccal pouch tumors. J Natl Cancer Inst 71: $1253-1264$

Ogiso H, Ishitani R, Nureki O, Fukai S, Yamanaka M, Kim JH, Saito K, Sakamoto A, Inoue M, Shirouzu M, Yokoyama S (2002) Crystal structure of the complex of human epidermal growth factor and receptor extracellular domains. Cell 110: 775-787

Overwijk WW, Lee DS, Surman DR, Irvine KR, Touloukian CE, Chan CC, Carroll MW, Moss B, Rosenberg SA, Restifo NP (1999) Vaccination with a recombinant vaccinia virus encoding a 'self antigen induces autoimmune vitiligo and tumor cell destruction in mice: requirement for CD4(+) T lymphocytes. Proc Natl Acad Sci USA 96: 2982-2987

Palm J, Silvers WK, Billingham RE (1967) The problem of histocompatibility in wild hamsters. J Hered 58: $40-44$

Park JM, Terabe M, Sakai Y, Munasinghe J, Forni G, Morris JC, Berzofsky JA (2005) Early role of CD4+ Th1 cells and antibodies in HER-2 adenovirus-vaccine protection against autochthonous mammary carcinomas. J Immunol 174: 4228-4236

Parkin DM, Bray F, Ferlay J, Pisani P (2001) Estimating the world cancer burden: Globocan 2000. Int J Cancer 94: 153-156

Quaglino E, Iezzi M, Mastini C, Amici A, Pericle F, Di Carlo E, Pupa SM, De Giovanni C, Spadaro M, Curcio C, Lollini PL, Musiani P, Forni G, Cavallo F (2004a) Electroporated DNA vaccine clears away multifocal mammary carcinomas in her-2/neu transgenic mice. Cancer Res 64: $2858-2864$

Quaglino E, Rolla S, Iezzi M, Spadaro M, Musiani P, De Giovanni C, Lollini PL, Lanzardo S, Forni G, Sanges R, Crispi S, De Luca P, Calogero R, Cavallo F (2004b) Concordant morphologic and gene expression data show that a vaccine halts HER-2/neu preneoplastic lesions. J Clin Invest 113: $709-717$

Resnick B, Farber EM, Fulton GP (1960) Survival of human skin transplanted into the cheek pouch of the golden hamster. Arch Dermatol 81: $394-399$

Rosenberg SA, Yang JC, Schwartzentruber DJ, Hwu P, Marincola FM, Topalian SL, Restifo NP, Dudley ME, Schwarz SL, Spiess PJ, Wunderlich 
DNA vaccination prevents oral squamous cell carcinomas GN Berta et al

JR, Parkhurst MR, Kawakami Y, Seipp CA, Einhorn JH, White DE (1998) Immunologic and therapeutic evaluation of a synthetic peptide EC-TM for the treatment of patients with metastatic melanoma. Nat Med 4: $321-327$

Rovero S, Amici A, Di Carlo E, Bei R, Nanni P, Quaglino E, Porcedda P, Boggio K, Smorlesi A, Lollini PL, Landuzzi L, Colombo MP, Giovarelli M, Musiani P, Forni G (2000) DNA vaccination against rat her-2/Neu p185 more effectively inhibits carcinogenesis than transplantable carcinomas in transgenic BALB/c mice. J Immunol 165: 5133-5142

Salley JJ (1954) Experimental carcinogenesis in the cheek pouch of the Syrian hamster. J Dent Res 33: $253-262$

Shklar G, Eisenberg E, Flynn E (1979) Immunoenhancing agents and experimental leukoplakia and carcinoma of the hamster buccal pouch. Prog Exp Tumor Res 24: 269-282

Spadaro M, Ambrosino E, Iezzi M, Di Carlo E, Sacchetti P, Curcio C, Amici A, Wei WZ, Musiani P, Lollini PL, Cavallo F, Forni G (2005) Cure of mammary carcinomas in Her-2 transgenic mice through sequential stimulation of innate (neo-adjuvant IL12) and adaptive (DNA vaccine electroporation) immunity. Clin Cancer Res 11: $1941-1952$
Trojan A, Witzens M, Schultze JL, Vonderheide RH, Harig S, Krackhardt AM, Stahel RA, Gribben JG (2001) Generation of cytotoxic T lymphocytes against native and altered peptides of human leukocyte antigen- $A^{\star} 0201$ restricted epitopes from the human epithelial cell adhesion molecule. Cancer Res 61: $4761-4765$

United Kingdom Co-ordinating Committee on Cancer Research (UKCCCR) (1998) Guidelines for the welfare of animals in experimental neoplasia. Br J Cancer 77: $1-10$

Vokes EE, Weichselbaum RR, Lippman SM, Hong WK (1993) Head and neck cancer. $N$ Engl J Med 328: $184-194$

Wollenberg B, Kastenbauer S, Mundl H, Schaumberg J, Mayer A, Andratschke M, Lang S, Pauli C, Zeidler R, Ihrler S, Lohrs U, Naujoks K, Rollston R (1999) Gene therapy - phase I trial for primary untreated head and neck squamous cell cancer (HNSCC) UICC stage II - IV with a single intratumoral injection of hIL-2 plasmids formulated in DOTMA/ Chol. Hum Gene Ther 10: $141-147$

Xia W, Lau YK, Zhang HZ, Xiao FY, Johnston DA, Liu AR, Li L, Katz RL, Hung MC (1999) Combination of EGFR, HER-2/neu, and HER-3 is a stronger predictor for the outcome of oral squamous cell carcinoma than any individual family members. Clin Cancer Res 5: 4164-4174 